\title{
APPLICATION ANALYSIS OF ONLINE LEARNER SKILLS AND KNOWLEDGE EVALUATION MODEL
}

\section{SUMMARY}

Introduction. Higher education institutions experience the reform of higher education, changing the conception of studies and learning scenarios and the forms of their implementation. Distance learning and teaching are efficient means to implement strategic aims of the system of education: to create learning possibilities for all members of the society, to implement lifelong learning at all education levels, to contribute to designing effective learning/teaching process and to meet quality requirements, as well as to ensure more flexible organization of learning activities meeting lifelong learners'needs.

The Aim of the Study. To analyse application of Online Learner Skills and Evaluation model (OLSKE) in a new distance learning and teaching curriculum.

Materials and Methods. The paper presents OLSKE, and discusses its application. The evaluation of the application of the model is performed by evaluating curriculum quality that was designed on the basis of the model applied, rather than the model itself. Therefore, the questionnaires distributed for the students and the experts are targeted at curriculum evaluation. Application of the model is crucial to curriculum structure, consistency and quality evaluation factors.

Results. Solutions for the realisation of the curriculum should be selected very carefully, as accessibility to learning resources should be ensured in all cases. Then, learning strategy and evaluation strategy should be very clearly designed and then presented to the learner, describing it with special attention in any chosen virtual learning environment.

Conclusions. University students positively evaluated the overall evaluation of the course curriculum and curriculum quality designed after applicability of OLSKE.

Keywords: lifelong learning, distance learning and teaching curriculum, online learner skills and knowledge evaluation model

\section{INTRODUCTION}

Lifelong learning contributes to the strategic goals of the development of the EU and its member countries, and it gradually becomes a real experience for each individual. The objectives of lifelong learning are formulated in different ways, but they should be based on the assessment of knowledge, competence and skills within the context of previous and current knowledge, skills, and competences (European Qualification Framework for Lifelong Learning, 2008).

The competence-based approach is chosen in this article as the subject of the article analysis of the application of OLSKE - concerns teachers and distance learning and teaching curriculum designers who plan and implement curriculum design. They apply reflective quality evaluation procedure during the whole design process (Volungeviciene, Tereseviciene, 2008), and they build the curriculum on the basis of the model. By this application, they demonstrate their competence-based and performance-based result - curriculum designed for distance learning and teaching. The model accompanies them during the design process, and the result of their success or failure is the curriculum itself, which then undergoes quality evaluation.

\section{THE AIM OF THE STUDY}

To analyse application of Online Learner Skills and Evaluation model (OLSKE) in a new distance learning and teaching curriculum. 
Research question addressed by this paper is how OLSKE, that was designed and programmed on the basis of prior research results, can be applied in distance learning and teaching curriculum development to ensure quality assurance of curriculum design and fulfil lifelong learning service provision requirements. With the limitations of the scope of the paper kept in mind, the aim of this research was defined, which is to analyse application of OLSKE in a new distance learning and teaching curriculum.

\section{Objectives of the research are the following:}

- To present OLSKE model;

- To demonstrate applicability of OLSKE model in a new distance learning and teaching curriculum;

- To present student evaluation results from the point of view of model applicability;

- To present expert evaluation results from the point of view of quality evaluation of the curriculum;

- To discuss the results of the model application from the point of view of lifelong learning services and quality assurance, and to present recommendations for the use of the model.

\section{MATERIALS AND METHODS}

As Whitty and Willmott state, 'competence- based approach to teacher education implies that competences play a more significant role in the planning and implementation of courses. All course design should be informed by characteristics of the learners who are to benefit from the course' (Whitty, Willmott 1995, 212).

Competence assessment process has always been as most challenging and most effort requiring phase of learning process, requiring validity and reliability. Curriculum quality assessment and learner satisfaction assessment are different subjects in this context, as not only that it should be objective, but also very tightly related to the learning objectives, learning methods, as well as influenced by additional factors that depend on the type of assessment, and the level of education institution that is involved in assessment process.

Besides that, other challenges occur in this context. Lifelong learning objectives can be achieved only using complex-methodology approach; for the studies at a higher education institution, especially a university, they become extremely important. Higher education institutions among their strategic goals foresee such objectives as 'to guarantee universal and continuing access to learning for gaining and renewing the skills needed for sustained participation in the knowledge society' and 'to develop effective teaching and learning methods and contexts for the continuum of lifelong and lifewide learning' (A Memorandum on Lifelong Learning, 2001, 4).

Higher education institutions with their professionals and academics experience the reform of higher education, changing the conception of studies and reviewing the roles of learning process participants, learning scenarios and the forms of their implementation, as required by lifelong learning services. Moreover, university studies, as studies aiming at research-based education service, should be continuously aimed at quality assurance and should guideline promotion for the best quality learning curriculum. Besides the fact that quality evaluation and assurance should be reflected in all phases of curriculum design, external factors, such as meeting the learner needs and ensuring accessibility to learning become of equal importance for researchers at education institutions.

This brings not only more challenges, but also stronger emphasis on constant update of skills, knowledge and competences among academics. While education services are aimed at knowledge, skills and competence development (Lauzackas, Pukelis, 2000; Teresevičienė 2001), these priority areas naturally become an important part and the target and guidelines for curriculum designers, who design evaluation strategies for learning outcomes. Competence approach helps different European countries and education institutions to reach the common 
agreement on recognition of learning outcomes. However, competence development is also a segmented process in itself, and it is aimed at consistent and complete training of citizens to prepare them for academic and professional activities. In other words, separate curriculum segments cannot ensure qualitative education services, as they are contextual elements of a complex and multifunctional process.

Distance learning and teaching is the efficient means to implement strategic aims of the system of education: to create learning possibilities for all society members (Moore, Kearsley, 2005), to implement lifelong learning at all education levels (Bates, 1995), to contribute to designing effective learning/teaching process and to meet quality requirements (Strother, 2002), as well as to ensure more flexible organization of learning activities meeting lifelong learners' needs. The use of information and communication technologies (ICT) in education allows development of different learning and teaching scenarios and realizing learning and teaching process virtually, using virtual learning environments.

While new distance learning and teaching forms are getting more and more popular, they should be reviewed regularly applying a consistent quality evaluation methodology based on quality criteria and indicators (Volungeviciene, Tereserviciene, 2008), and distance learning and teaching curriculum quality should be examined before each learning and teaching process. On the other hand, the results of such quality evaluation and assessment should be analysed by the researchers at education institutions in order to validate the chosen learning and teaching scenarios with teachers and learners, and suggest scenario modifications in case of negative feedback or evaluation on existing ones.

OLSKE was developed as previous research result and was presented in previous publications in detail (Rutkauskiene, Volungeviciene, Tereseviciene, 2006). This article will shortly remind the theoretical background, but will focus on applicability issues. The model was applied designing distance learning and teaching curriculum 'Adult learning'. The curriculum was designed maintaining chronological and segmental sequence of the model, and the course was realized using Blackboard virtual learning environment and online tools designed on the basis of OLSKE model. The curriculum and learning organization process was evaluated from the point of view of quality by 20 university students, participating in 'Adult learning' course, and then by 2 external experts. Learners used both, Blackboard virtual learning environment and OLSKE model. Evaluation was performed using quality evaluation criteria grids designed on the basis of research performed by the authors of this article. University students used evaluation questionnaires presented using OLSKE model tools, and experts used printed questionnaires and provided assessment of quality evaluation factors analysis results, as well as descriptive feedback about the course curriculum.

The rest of the paper presents OLSKE model, and then discusses the application of the model. The evaluation of the application of the model is performed by evaluating curriculum quality that was designed on the basis of the model applied, rather than the model itself. Therefore, the questionnaires distributed for the students and the experts are targeted at curriculum evaluation. Application of the model is crucial to curriculum structure, consistency and quality evaluation factors (described in more detail by Volungeviciene, Tereseviciene, 2008).

\section{OLSKE Model}

Despite current changes that are now in progress in the area of education, there are problematic areas that change very slowly, as they are influenced by curriculum development innovations and need special attention and quality assurance discussion. Evaluation of knowledge and skills is often such a case. Learner skills and knowledge evaluation is often the phase when learners are formally accounting for the knowledge that was gained during learning. The existing system of evaluation and assessment is relatively narrow and is not flexible enough. Such system creates conditions for the teacher to gain advantages over the learner during the evaluation 
process. The student feels insecure, intimidated and not self-confident, as the student does not know when s/he will be asked to demonstrate the knowledge for the purpose of evaluation, in which way s/he will have to do this and which criteria will be applied to give evaluation for the assessment. Moreover, teachers are not always able to review and evaluate the quality of the curriculum that they develop, thus they base their design decisions on their intuition and personal experience and attitude.

Researchers working in assessment design in the context of curriculum development (Leclercq, 1998; Black et al., 1998; Hyba, Freed, 2000; Lauzackas, 2001; Tereseviciene, Gedviliene, 2003) agree that the evaluation process in an institution should reflect the student's learning objective, what the student achieved so far, how the learning process was organised, if learner's individual learning needs are taken into consideration, including learning tempo and learning methods, especially in lifelong learning service perspective. Other issues should be considered, as well, like if assessment is adequate to the changes in the study process which affect the student's learning and motivation, and which would orient the student to become a lifelong learner (Zuzeviciutè, Teresevičienè, 2007).

Designing evaluation of learning outcomes on the basis of evaluation strategy built on competence assessment (Pukelis, Pileičikienè, 2005) and evaluation of reaching the learning objectives (Leclercq, 2005; Lauzackas, 2001, and others), curriculum designers should keep in mind active involvement of learners inviting them to control and monitor their learning process consciously by metacognitive activities (Leclercq, Poumay, 2003). (Abell, 2003) recommends initiating metacognitive learning activities in the early stages of learning.

The research performed by the joint group of sciences representing education and technology specialists aimed to provide theoretical background and methodological recommendations for evaluation of the learner's knowledge and skills online. Besides designing evaluation strategy, OLSKE model aimed at helping curriculum designers to define curriculum conception, in order to have the overall view of learning strategy (Rosenberg, 2001) and the context for designing learning activities and learning outcomes' evaluation. Online curriculum designers may use the model to design consistent curriculum, ensuring that learning objectives, learning methods and evaluation are consistent among themselves. They may also evaluate curriculum quality factors during the design phase. Instructors/ teachers may use learning interface to deliver learning, but they may edit curriculum elements during the learning process in order to improve curriculum solutions (if applicable) and to satisfy lifelong learners' needs. They may also track learner records, feedback and evaluation questionnaires' results.

The model designed also reflects competences that the teacher should gain in order to assess the learners in a distance education course on the basis of confidence and reliability. And this is directly addressed in this paper. When we speak about evaluation in this article, we mean the process during which the data are collected about the learning process, about the learner's achievements and competences. However, by designing distance learning and teaching curriculum, teachers and course authors demonstrate their own competences to design qualitative curriculum. By the term competence we mean functional abilities to perform a certain activity adequately, i. e. demonstrating a concrete ability to perform one or another function during a certain activity (evaluation, assessment or other). Teacher competences realized in the model are presented in Picture 1.

There are seven competences described that are necessary for the teachers and course authors. Each competence acquisition may be demonstrated and facilitate by the tools provided in OLSKE model, as they were designed and implemented using ICT. The tools are the means to help the teachers to design their distance learning and teaching curriculum and to maintain the triple consistency of learning objectives, methods and evaluation, in other words, the model helps to follow this consistency by 'checking' whether the evaluation strategy is based or reflects the learning objectives defined in the course. 


\section{Competences for OLSKE}
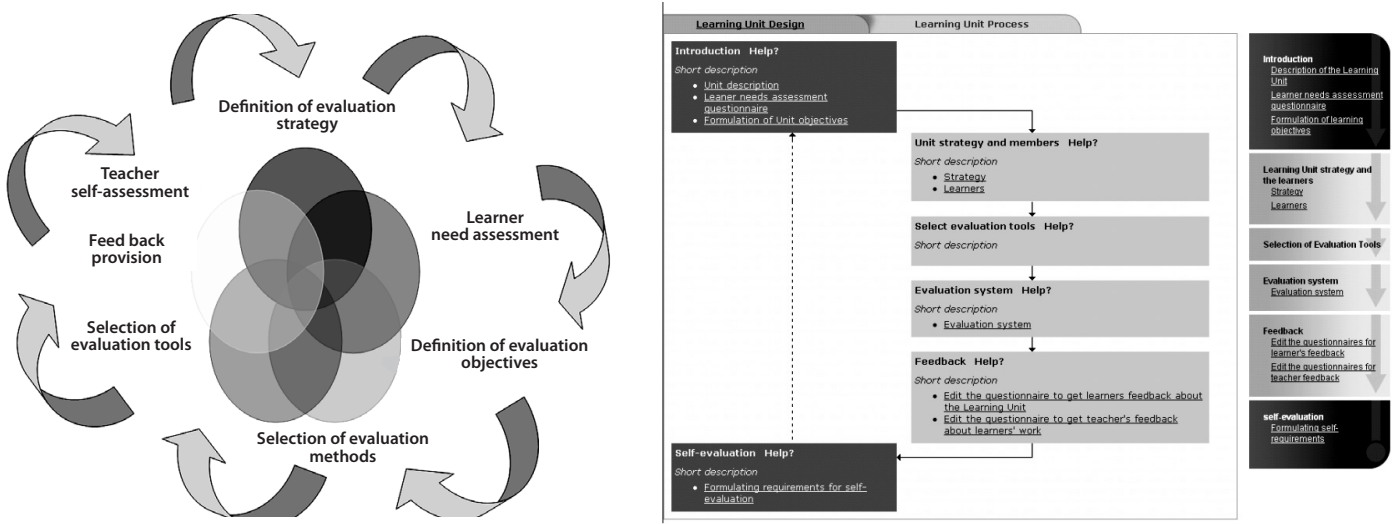

Picture 2 demonstrates the steps that the teacher implements in order design a consistent distance learning course, as this is the main purpose of the model.

In the Picture above, it can be seen that learning design interface suggests to start with finding out learners' needs, setting the learning objectives consistent with the evaluation based on learning outcomes, and then, the strategy and learning activities need to be selected, as well as strategy implementation tools.

The development of the model was based on different research findings and methodological recommendations, including organisation of learning evaluation process (Lecercq, Poumay, 2003), motivation factor analysis (Viau, 1994), positive and negative effects of evaluation process (Lauzackas, 2001), and other theoretical literature findings, and it was described in detail by the authors of this article in previous publications (Rutkauskiene, Volungeviciene, Tereseviciene, 2006). The model was defined on the basis of learning objective definition theory (Lauzackas, 2001) and Bloom's taxonomy of learning objectives (Krathwohl, Bloom, Masia, 1964), different learning activity and learning evaluation scenarios experienced in educational settings. Formative evaluation and self-assessment tools were designed on the basis of the ideas presented by Leclercq and Poumay (Leclercq,Poumay 2005) theory of 'partial knowledge' and self assessment instruments, aiming at realization of the ideas of metacognition and self-evaluation.

Picture 3. OLSKE model: tools guiding the definition of learning objectives

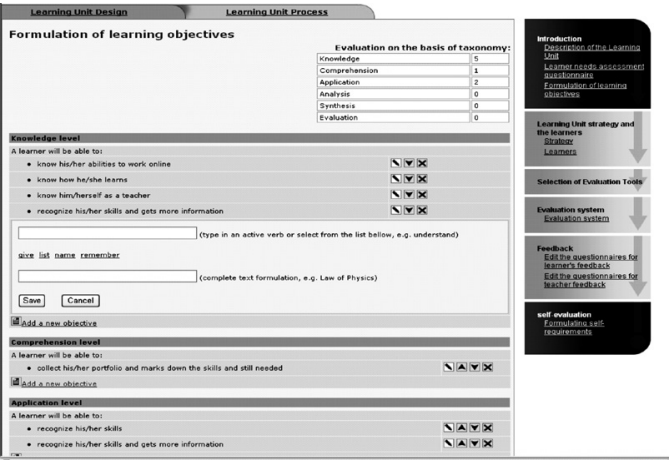

Picture 4. Different ways to organize learning (verbally, logically, spatially, musically, interpersonally, internally, kinaesthetically, etc.; Teresevičiene, Oldroyd, Gedviliene 2004)

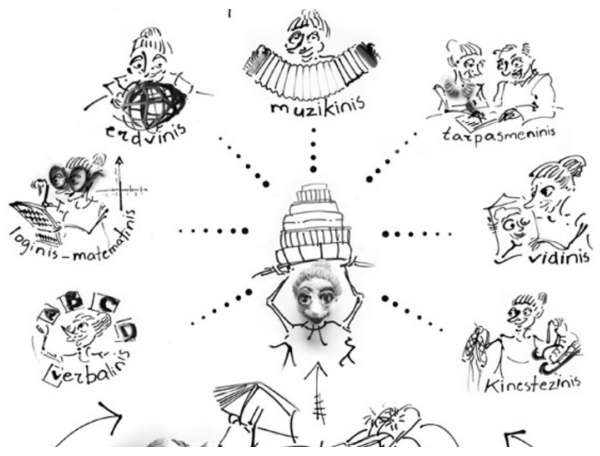


Thus, different tools correspond with the phases of curriculum design. OLSKE model tools accompany teachers/designers realizing curriculum design online via the following phases:

- Selection and description of competences that will be mastered by learners at the end of the learning/teaching process;

- Designing the learner-needs questionnaires, in order to get information on specific learner needs. This was planned to ensure equal accessibility to learning despite of specific individual needs of all participants, not influencing the learning content, but rather learning process organization and online learning support;

- Formulation of learning objectives (online tools guiding the teachers through Bloom's taxonomy, indicating the levels of objectives covered, see Picture 3;

- Selecting the strategy for learning and evaluation strategy, with the options of project work, testing, group and individual work and tasks for assessment, as well as additional open task forms that would be influencing the assessment;

- Evaluation process is divided into:

- Knowledge and skills evaluation and assessment on the basis of evaluation strategy chosen beforehand (teacher evaluation and assessment, as well as peer evaluation and assessment are possible to implement);

- Teacher and learner self-assessment, as well as learning unit assessment tools are designed for overall quality evaluation of overall learning and teaching strategy.

The conception of learning objective defines a certain status, situation that is to be achieved by the participants of the learning process during their learning. Most frequently, they comprise psychological and physical dispositions of the learner decided by his/her behaviour.

The following criteria were chosen for formulation of an objective (Lauzackas, 2001):

- An objective indicates the final learner's behaviour, i. e. what s/he should be able to do at the end of the learning process (the whole learning program of a certain phase);

- An objective indicates the conditions for this behaviour (indicating the type of, etc.);

- An objective is a criterion for a learner's behaviour;

- Thus the formulation of a learning objective should meet three conditions, i. e. should indicate:

- Final behaviour of the learner;

- The conditions upon which this behaviour is expressed;

- The minimum requirements for this expression of the behaviour.

An example is presented in the table below:

Table 1. An example of formulation of learning objectives (Lauzackas, 2001)

\begin{tabular}{|c|c|c|c|}
\hline $\begin{array}{c}\text { 1. Introductory part of } \\
\text { the sentence }\end{array}$ & $\begin{array}{c}\text { 2. An active verb } \\
\text { of phrase }\end{array}$ & 3. An object & $\begin{array}{c}\text { 4. The context and the } \\
\text { conditions }\end{array}$ \\
\hline \multirow{2}{*}{$\begin{array}{c}\text { After the learning } \\
\text { process, a learner will be } \\
\text { able to... }\end{array}$} & $\begin{array}{c}\text {..to explain... } \\
\text { to evaluate... }\end{array}$ & $\ldots$ consistency... & $\begin{array}{c}\text {... between the learning } \\
\text { objectives, methods and } \\
\text { evaluation. }\end{array}$ \\
\cline { 2 - 4 } & $\begin{array}{c}\text {..to define... } \\
\text { to illustrate... }\end{array}$ & $\begin{array}{c}\text {...principles of and } \\
\text { differences between... }\end{array}$ & $\begin{array}{c}\text {...formative and summative } \\
\text { evaluation }\end{array}$ \\
\cline { 2 - 4 } & ...to explain... & $\ldots$...self-assessment... & $\begin{array}{c}\text {...activities and their } \\
\text { importance. }\end{array}$ \\
\hline
\end{tabular}

Getting back to the process of evaluation, we should mention that one of the most effective principles of evaluation is participation of the learner himself/ herself in the evaluation process. The learner evaluates his/ her own competences (by self-assessment) and gains evaluation bonuses for self-assessment also. Several scientists suggested adding extra bonus for the learner 
on the basis of his/her degree of certainty for their answers and certainty of correct information in their answers (Leclercq, Poumay, 2003). The theory is based on metacognition which is often limited in education with the learner's self-cognition. When we speak about metacognition, we have in mind the activity during which an individual analyses the learning strategies, find out and evaluates the thinking process in retrospective events, evaluates the performance and results, and analysis overall situation with the purpose to gain more benefit from the process in the future.

Leclercq and Poumay (Leclercq, Poumay 2003) suggested three levels of the activity of meta-cognition:

- Judgment of the performance (satisfactory or not, correct or not, etc.);

- Analysis of the situation (reasons, diagnosis);

- Regulation or decision to act.

The presence of these three terms will be noticed in various authors' definitions, but they are rarely gathered together in the same definition. They also distinguish three situations in which the learner may find himself in order to conduct these metacognitive activities:

- Before the performance;

- During the performance;

- After the performance and after its evaluation by an expert, or comparison with the performance of peers.

All three phases are enabled for the curriculum design, and moreover, if the learner or the teacher wants, the number of times when self-evaluation is performed might be bigger, this is the issue of technical realization. These opportunities are designed by realizing OLSKE model online. This paper has the objective to evoke metacognition of the third phase, when expert evaluation of the curriculum was performed, as well as learner evaluation was collected and analyzed.

After the conception of the learning and teaching strategy is designed, either OLSKE model can be used to realize distance learning and teaching, or another online learning platform can be used instead. However, learners and teachers keep reference to the existing conception of curriculum designed with the help of the model described.

\section{Development}

Application of OLSKE Model in a Distance Learning/Teaching Curriculum

Curriculum for a distance learning/ teaching course 'Adult Learning' was designed on the basis of OLSKE model and its tools for realization of curriculum conception. The curriculum conception and course environment are different, as the course was delivered online using Blackboard virtual learning environment.

The learning objectives for the course 'Adult Learning' were defined on the basis of B. Bloom taxonomy, and specific objectives were related with the four learning units designed to reach general course objectives. Learner needs questionnaire was also designed using OLSKE model and its tools.

The conception of the curriculum was based on the concept mapping (Rowley, 2006). Learners were able to freely navigate and choose learning unit at random, as curriculum was not designed in a strict order of appearance, but rather flexible in acquisition of the main competences, as well as specific learning goals. Then curriculum suggested different activating scenarios where learning activities were based on similar type of earning scenarios in each part of the course, and symbolic icons related scenarios with similar sequence in all parts, suggesting the learners:

- Reading and receiving of information (theoretical readings and video lectures, including certain emphasis on research findings and epistemology, as well as factual information);

- Practicing and application of theory in practice (example analysis and practical tasks);

- Discussing and arguing activities (discussion topics suggested after readings);

- Exploring (critical thinking ideas, to be discussed and supported by personal findings afterwards).

The curriculum of 'Adult Learning' distance education course is designed maintaining 
the principle of isomorfism, suggesting a variety of learning scenarios and approaches to learning activities, and encouraging the learners for exploration and creation - learners developed adult learning activities themselves. The course conception and structure can be illustrated by a screenshot from the course itself (see Picture 4).

Evaluation and assessment was realized in different ways in the course online environment, including:

- Peer evaluation in discussion area (Sengupta, 1998; Teresevičienė, 1997);

- Intermediate cognitive evaluation tests in each course topic;

- Final examination consisting of an open task and cognitive evaluation in a test form;

- Self-assessment tests integrated in theoretical part of the course (Black, Wiliam, 1998).

At the end of the pilot testing, the curriculum was assessed by learners and experts giving feedback to curriculum developers on improvement of curriculum conception and realization.

\section{Learner evaluation results}

Learner evaluation was performed by distributing online questionnaire using OLSKE model and its tools. The questionnaire was designed on the basis of quality evaluation factors that need to be assessed during curriculum development. The main parts of the quality evaluation questionnaire were addressing:

- The overall evaluation of the course curriculum;

- Curriculum quality evaluation;

- Realization solutions at virtual learning environment;

- Learning and teaching process, and administration of learning.

There were 20 university students that participated in the pilot evaluation of the distance education course 'Adult learning'. The participants were the students of Andragogy study program in the department of Education at Vytautas Magnus University. The course was piloted for 2 months, and the participants filled in the online questionnaire after they completed the course.

Providing the opinion on the overall course curriculum, they indicated their opinion on the following issues:

a) How interesting it was to read the theoretical material;

b) How learning was important for practical application purposes;

c) How much curriculum was presented clearly and in an understandable way;

d) How much the curriculum corresponds to learning objectives;

e) If the material is illustrated and visualized enough;

f) If the participants gained additional competences necessary for learning online;

g) If participants would recommend this course to the colleagues;

h) If the experience in this course will evoke positive changes in their education institutions;

i) If participation in this course is an added value to their qualification improvement.

The responses of the participants are presented in Picture 5.

The overall evaluation of the course curriculum is very positive, with only 2 respondents indicating not compete satisfaction with different criteria, and sometimes only one or three who are partly satisfied with the solutions and decisions accepting during course curriculum development.

The second part of the evaluation questionnaire is dedicated as mentioned above to Curriculum quality evaluation, indicating: a) how clearly learning objectives are presented to the learner, b) how course guide helpful is, c) how learning activities are clear, d) if the learning material helps to reach learning objectives, e) if learning material is clear to learners, f) if learning met personal needs, g) if tripe consistency was maintained, h) if practical skills were developed, i) if evaluation strategy was clear, j) if different learning styles were addressed, k) if participants think that they reached learning objectives successfully.

As results of learners' evaluation and feedback on the curriculum quality show (see 

the course curriculum evaluation by learners

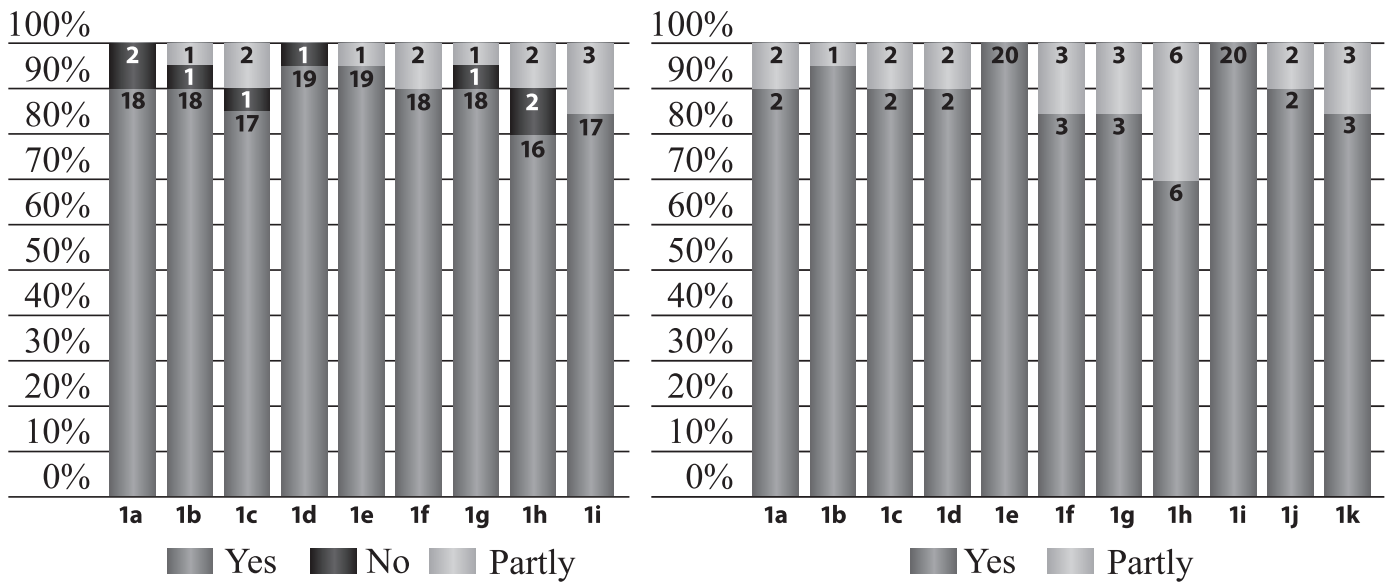

Picture 6), they are absolutely satisfied with the evaluation strategy chosen, and they have most critical remarks on the lack of practical skill development (6 respondents were not satisfied with the level of practical skill development methods used in curriculum). However, there is no doubt that evaluation results are very high.

The third part of the evaluation questionnaire was dedicated to assess realization solutions of the curriculum at virtual learning environment. The following aspects were evaluated: a) page navigation speed, b) links and references access speed, c) access of video and audio material, d) triggers to access all learning material, e) technical support provision, f) course structure, g) navigation within the course, h) navigation icons clear, i) font size, j) colours chosen; and then the questions were asked related internet access: $\mathrm{k}$ ) at home, l) at work, $\mathrm{m}$ ) in a café; as well as PC use: n) at home, o) at work, p) in a café, q) I used printed material of the course. The evaluation results showed the following tendencies (see Picture 7):

Picture 7. Evaluation of the curriculum realization at virtual learning environment

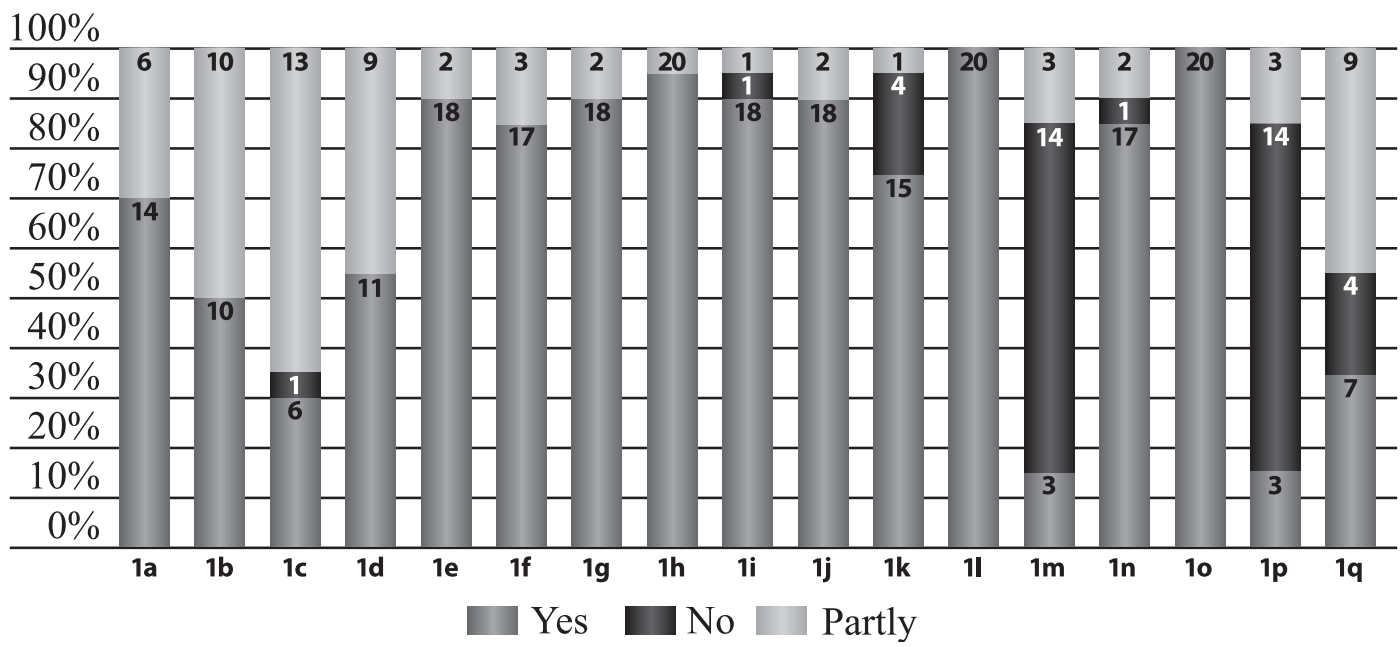


The last part of the questionnaire distributed for the course participants asked them for their opinion on learning - teaching process, as well as learning administration issues. The respondents were asked if they agree that: a) intense communication was going on during the course among participants and the tutor, b) the tutor encouraged for active participation, c) individual support was provided for the learners, d) there was enough time for activity performance dedicated, e) tutors were very professional, f) tutors demonstrated professional subject knowledge, g) administration was timely and subject addressed, h) feedback was always provided.

Having a very positive evaluation of learners, the intermediate outcomes and conclusions can be indicated here, stating that management problems might be noticed, like lack of time for activities and homework during the learning process, as well as improvement of online realization solutions are required. Learners were not able to access all resources easily due to technical problems. However, curriculum quality evaluation was highly positive.

Now it is the right time to see external expert evaluation that is related with the curriculum conception rather than application of ICT and administration of learning process. Both, learner and expert evaluation were performed in parallel, but not related to each other.

\section{Expert evaluation results}

The course curriculum was evaluated by 2 experts (distance learning and teaching methodology experts, having designed curriculum for higher education institutions and colleges in Lithuania), anonymously, and the results were provided for the course designers for course curriculum improvement. The evaluation questionnaire was based on distance learning/ teaching quality evaluation factors that were included in the ongoing research at Vytautas Magnus University performed by the authors of this paper. The questionnaire for expert evaluation maintained only these groups of factors that can be evaluated during the external evaluation. They included:

- Overall evaluation of the curriculum conception;

- Evaluation and analysis of the resources;

- Formulation of learning objectives;

- Learning organization methods used in curriculum;

- Support provision;

- And evaluation strategy in the course.

Experts were asked to identify how these quality evaluation factors were addressed in the curriculum, and they were asked to indicate their decision by responding the following ways (in the majority of questions): 'yes', indicating a positive response, 'no', indicating a negative response, and they were asked to provide recommendations for improvement, 'it is difficult to say', when they were not sure about the evaluation and identification.

The results of expert evaluation show the following:

- The course of the structure is very clear and clearly presented;

- The main parameters of the curriculum are clearly consistent with each other;

- Learning methods are consistent with the evaluation methods and help to reach learning objective;

- Knowledge evaluation tests are consistent with learning objective definitions in terms of concepts and formulated questions;

- Learning activities are based on practical training; and practical skills development is evidently the main focus of curriculum;

- Course guide information should include direct guidance for tutors and teachers about their roles in the course and training methods;

- The majority of learning methods are used in the course; including transfer of information; individual learning; practical application of knowledge; critical thinking; development of skills allowing to act individually; and reflection; 
- Evaluation strategy is clearly presented in OLSKE model, but it is not very clearly described in the course guide.

Experts concluded that during the curriculum development, the following quality evaluation factors were evaluated: definition of learning objectives (they are defined measurably and they are presented clearly in the course), different learning methods (they are consistent with the learning objectives), support system, communication means, and evaluation strategy.

Experts indicate the following quality evaluation factors that should be more carefully evaluated in curriculum design: the use of different existing online resources, presentation form of learning activities, learning support tools, learner participation in evaluation strategy development, and experts are not sure about the teacher reflexive feedback tools to be used in the course.

Expert evaluation and learner evaluation results prove that OLSKE model helps teachers/ designers to maintain distance learning/teaching curriculum consistency. Learners and experts provided high evaluation rank for the quality criteria in curriculum designed using OLSKE model, thus it can be stated that the model contributes to quality improvement of distance learning/ teaching curriculum. The structure of curriculum and strategy of learning is also positively evaluated by learners and experts. However, there are some possible implications of the use of the model to distance learning/teaching curriculum that need to be reviewed and commented.

First, evaluation results should be further explored and researched, as well as evaluated by broader audience and respondent groups. However, the results achieved within this survey suggest that curriculum realization solutions should be very carefully selected, as accessibility to learning resources should be ensured in all cases. Then, learning strategy and evaluation strategy should be very clearly designed and then presented to the learner, describing it with special attention in any chosen virtual learning environment. This implies that lifelong learning service provision requirements remain very individual in each case, depending on the target lifelong learners' needs. These may cover accessibility, time management and strategic planning of learning activities, etc.

These problematic aspects can be solved using ready-made OLSKE model tools, namely, feedback provision tools, learner satisfaction questionnaires, as well as learner needs evaluation tools. These tools may bring preventing actions for such problems. It should be taken into consideration that these aspects retain lifelong learning service provision requirements, but they should always be consistent with the quality requirements, when the latter ones remain with bigger weight in final decision.

\section{Conclusive remarks}

This paper analyses application of OLSKE model. The analysis and evaluation was performed by student evaluation and expert evaluation focusing on curriculum quality. The following objectives were reached in this paper:

- OLSKE model was presented, adding online tools description and applicability options;

- Applicability of OLSKE in a new distance education curriculum called 'Adult learning' was demonstrated;

- University student evaluation results from the point of view of model applicability were presented, which were summarised as follows:

- The learners positively evaluated the overall evaluation of the course curriculum and curriculum quality;

- Curriculum realization solutions at virtual learning environment need to be improved with easier - access solutions;

- Learning and teaching process is organized smoothly, just more time is needed for learning activities and tasks.

- Expert evaluation results from the point of view of quality evaluation of the curriculum were presented that indicated the following general conclusions:

- Course learning objectives are formulated very clear and in a measurable way; 
- Different learning methods are used in the curriculum, but they are consistent with the learning objectives and help to reach evaluation objectives;

- Evaluation strategy is not very clearly presented in the course (expert notification), but they are consistent with the definition of evaluation strategy and learning objectives, as confirmed by the learners of the course;

- Some quality evaluation factors should be paid more attention while developing course curriculum, including the use of resources, presentation form of learning activities, learning support tools, learner participation in evaluation strategy development, and experts are not sure about the teacher reflexive feedback tools to be used in the course.

- The results of the model application from the point of view of lifelong learning services and quality assurance were discussed and the following recommendations for the use and improvement of the model were defined:

The following recommendations for the use of OLSKE can be defined:

- OLSKE model is helpful for qualitative distance education curriculum designing, including consistency and quality assurance criteria reviewing;

- OLSKE model can be used to demonstrate flexible solutions when curriculum design problems can be solved during learning process, as the model contains the tools that are linked within two interfaces (learning design and learning process);

- OLSKE model is useful for the use of curriculum design, learning process and support provision, as it allows curriculum design evaluation and improvement.

The following recommendations for the improvement of the model can be defined for the authors of the model:

- Consistency between learning objectives and learning outcomes' evaluation tools might be improved by programming solutions based on education research and theoretical models;

- Consistency between learner needs and learning administration might be improved by adds-on to the existing tools within the model;

- Additional tools would be needed to ensure curriculum presentation to the learner, improving accessibility, clear presentation of the curriculum items and easier communication and administration.

- User managing and interoperability with other virtual learning environments and online systems would increase the use of the model and easier transfer of the content to a new context.

\section{REFERENCES}

1. A Memorandum on Lifelong Learning (2001). EC, Brussels, p. 4.

2. Abell, M. (2003) Deepening Distributed Learning: Motivating Soldiers to Learn, Grow, Achieve. Proceedings of the Conference Interservice/Industry Training, Simulation and Education 2003, November, 2003, Orlando, Florida, USA, https://www.spider.hpc.navy.mil/index.cfm?top_ level=TX1_OT_1000133\&taxonomy= TX1. (October, 2007)

3. Bates, A. W. (1995) Technology, Open Learning and Distance Education. London: Routledge, 265 p.

4. Black, P., Wiliam, D. (1998) Assessment in Education: Principles, Policy \& Practice. In: Assessment and classroom learning. http://web.ebscohost.com/ehost/detail?vid=2\&hid=102\&sid=e0c73a2c7a33-4c74-a2eb-9e1deef3b14b\%40sessionmgr108. (April, 2009)

5. European Qualification Framework for Lifelong Learning (2008) http://ec.europa.eu/education/ policies/educ/eqf/eqf08_en.pdf. (June, 2009)

6. Krathwohl, D. R., Bloom, B. S., Masia, B. B. (1964) Taxonomy of Educational Objectives: Handbook II: Affective domain. New York: David McKay Co. http://classweb.gmu.edu/ndabbagh/Resources/ Resources2/krathstax.htm (June, 2009) 
7. Lauzackas, R. (2001) Mokymo turinio projektavimas [Planning of Education Content]. Kaunas: VDU, p. 143. (in Lithuanian)

8. Lauzackas, R., Pukelis, K. (2000) Kvalifikacija ir kompetencija: samprata, santykis bei struktūra profesijos mokytojo veiklos kontekste [Qualification and Competence: Conception, Proportion and Structure in the Context of Work of Occupational Instructor]. In: Lauzackas, R. (Ed.) Profesinis rengimas: tyrimai ir realijos [Professional Formation: Studies and Realities], Vol. 3, 155 p. (in Lithuanian)

9. Leclercq, D. (1998) Conception d'Interventions et Construction de Produits de Formation [Comprehension of Interventions and Building of Products of Training]. Liège: Université de Liège, Faculté de Psychologie et Sciences de l'Education, 245 p. (in French)

10. Leclercq, D. (2005) Edumetrie et Docimologie pour practiciens chercheurs [Edumetrics and Docimologics for Practical Researchers]. 2e Licence en Science de l'Education. Liege: Edition de l'Universite de Liege, 286 p. (in French)

11. Leclercq, D., Poumay, M. (2003) Analyses édumétriques et indices métacognitifs appliqués aux questions des 10 check-up MOHICAN [Edumetrical Analyses and Metacognitive Indications Applied to Questions of 10 Examination MOHICAN]. In: Leclercq, D. (Ed.) Diagnostic cognitif et métacognitif au seuil de l'université [Cognitive and Metacognitive Diagnosis at the Beginning of the University]. Liège: les Editions de l'université de Liège, p. 181-190, http://www.labset.net (July, 2007) (in French)

12. Leclercq, D., Poumay, M. (2005) The 8 Learning Events Model and its Principles. http://www.labset. net/media/prod/8LEM.pdf. (June, 2008)

13. Moore, M., Kearsley, G. (2005) Distance Education: A Systems View, 2nd edition. Thomson: Wadsworth, $195 \mathrm{p}$.

14. Pukelis, K., Pileičikienè, N. (2005) Studijų kokybė: studijų rezultatų paradigm [Study Quality: Results of the Study Paradgim]. In: Pukelis, K. (Ed.) Aukštojo mokslo kokybe [Quality of Higher Education], Vol. 2, p. 96-107. (in Lithuanian)

15. Rosenberg, M. J. (2001) E-Learning Strategies for Delivering Knowledge in a Digital Age. Mc-GrawHili professional, $338 \mathrm{p}$.

16. Rowley, T. (2006) Teaching Diversity Online: Using Concept Maps to Enhance Learning Outcomes. In: Canas, A. J., Novak, J. D. (Eds.) Concept Maps: Theory, Methodology, Technology. Retrieved from http://cmc.ihmc.us/cmc2006Papers/cmc2006-p85.pdf

17. Rutkauskiene, D., Volungeviciene, A., Tereseviciene, M. (2006) Learner's Skills and Knowledge Evaluation Model. In: Dagiene, V., Mittermeir, R. (Ed.) Information Technologies at School, Selected papers of the $2^{\text {nd }}$ International Conference Informatics in Secondary Schools: Evaluation and Perspectives, 2006, Vilnius, Lithuania. Institute of Mathematics and Informatics: Publishing House TEV, p. 632-642.

18. Sengupta, S. (1998) Peer Evaluation: 'I am not the Teacher'. In: ELT Journal, No 52(1). Oxford University Press, p. 19-28,

19. Strother, J. (2002) An Assessment of the Effectiveness of e-Learning in Corporate Training Programs. In: International Review of Research in Open and Distance Learning, Vol. 3, No. 1, ISSN: 1492-3831. Retrieved from http://www.irrodl.org/index.php/irrodl/article/view/83/161.

20. Teresevičienè, M. (1997) Grupès nuolatinio mokymosi sistemoje: mokymosi mažose grupėse principai [Groupings in the System of Life-long Learning: Learning Principles in Small Groups]. In: Sernas, V., Beresnevičienė, D., Teresevičienė M. (Eds.), ir kt. Nuolatinis mokymasis besikeičiančioje visuomeneje: prielaidos ir prieštaravimai [Continuous Learning in a Changing Society: Preconditions and Contradictions]. Kaunas: VDU, p. 73-79. (in Lithuanian)

21. Teresevičienè, M. (2001) Mokymosi visa gyvenima edukologinés dimensijos. Habilituoto daktaro disertacijos rankraštis [Educological Dimensions of Life-Long Self-Education. Doctoral Thesis]. Kaunas: VDU, p. 156. (in Lithuanian)

22. Tereseviciene, M., Gedviliene, G. (2003) Group Learning: Influence on Cognitive and Social Development. Pedagogija: teorija un prakse II. /Teaching and Learning in Democratic Society/. D. 2, p. 186-195. 
23. Teresevičienè, M., Oldroyd, D., Gedvilienè, G. (2004) Suaugusiuju mokymasis [Adult Learning]. Kaunas: VDU, 115 p. (in Lithuanian)

24. Viau, R. (1994) La motivation en contexte scolaire [Motivation in School Context]. Bruxelles: De Boeck, Coll. Pédagogie en développement. Retrieved on May, 2004. (in French)

25. Volungeviciene, A., Tereseviciene, M. (2008) Quality Assessment Dimensions of Distance Teaching/ Learning Curriculum Designing. In: Pukelis, K. et al., (Eds.) The Quality of Higher Education, № 5, Kaunas: Morkunas ir ko, p. 32-53.

26. Whitty, G., Willmott, E. (1995) Competence Based Teacher Education: Approaches and Issues, Chapter 18. In: Kerry, T., Mayes, A. Sh. (Eds.) Issues in Mentoring. New York: Routledge, p. 212.

27. Zuzevičiutè, V., Teresevičienè, M. (2007) Universitetinès studijos mokymosi visa gyvenima perspektyvoje [Self-Education in the University Studies in a Life-Long Perspective]. Monografija. Kaunas: Vytauto Didžiojo universitetas, 200 p. (in Lithuanian)

\section{Prof. Margarita TERESEVIČIENE்}

Head of the Department of Education

Vytautas Magnus University

Addres: Kaunas, LT- 44248, Lithuania

Phone: +370 37327821

E-mail: m.tereseviciene@smf.vdu.lt

\section{Prof. Genutė GEDVILIENE்}

Department of Education

Vytautas Magnus University

Addres: Kaunas, LT- 44248, Lithuania

Phone: +370 37327821

E-mail: g.gedviliene@smf.vdu.lt

\section{Lecturer Dr. Airina VOLUNGEVIČIENĖ}

Head of Distance Study Centre

Department of Education

Vytautas Magnus University, Kaunas

Addres: Kaunas, LT- 44248, Lithuania

Phone: +370 37327821

E-mail: a.volungeviciene@dsc.vdu.lt 